Cronfa - Swansea University Open Access Repository

This is an author produced version of a paper published in:

Greece and Rome

Cronfa URL for this paper:

http://cronfa.swan.ac.uk/Record/cronfa35220

\title{
Paper:
}

Goh, I. (2015). THE END OF THE BEGINNING: VIRGIL'S AENEID IN OVID, AMORES 1.2. Greece and Rome, 62 (02), 167-176.

http://dx.doi.org/10.1017/S0017383515000042

This item is brought to you by Swansea University. Any person downloading material is agreeing to abide by the terms of the repository licence. Copies of full text items may be used or reproduced in any format or medium, without prior permission for personal research or study, educational or non-commercial purposes only. The copyright for any work remains with the original author unless otherwise specified. The full-text must not be sold in any format or medium without the formal permission of the copyright holder.

Permission for multiple reproductions should be obtained from the original author.

Authors are personally responsible for adhering to copyright and publisher restrictions when uploading content to the repository. 


\section{THE END OF THE BEGINNING: VIRGIL'S AENEID IN OVID, AMORES $1.2^{\star}$}

It is well known that Ovid's Amores begin with a reference to Virgil's Aeneid in the very first word, arma ('weapons', Am. 1.1.1 = Verg. Aen. 1.1), which implies that the elegist had been composing epic before Cupid, by stealing a foot, apparently forced him to write elegy. ${ }^{1}$ In spite of this incapacitation at the hands of the love god, Ovid continues to toy with Virgil's epic by making the first two poems of his collection of elegiacs into a mini-Aeneid, ${ }^{2}$ or - to be precise - by making the second poem of the collection into the second half of the Aeneid. ${ }^{3}$ One result is that the three-book edition of Amores threatens to be over even before it has begun. Another is that Ovid can be identified with the Latin enemies, on the wrong side of history, from the Aeneid. I restrict the argument largely to what can be observed in Amores 1.2, leaving aside, for instance, the possibility that Ovid shot by Cupid's arrow in 1.1 might be thought comparable to Dido, similarly shot and causing Aeneas to dally in Carthage with her in Aeneid 4.

\footnotetext{
* I would like to thank many people for help and advice with this article, especially friendly colleagues from Manchester - Roy Gibson, Ruth Morello, Andrew Morrison, and Alison Sharrock and an anonymous reviewer. All translations are my own, though they may allude to those of others.

${ }^{1}$ This holds true even if reference is being made to the first, five-book (therefore bigger) edition of the Amores: see A. Barchiesi, Speaking Volumes. Narrative and Intertext in Ovid and Other Latin Poets (London, 2001), 159-61. So, too, if arma + bella ('arms' and 'wars', Am. 1.1.1) verbally cues the Aeneid's 'proem in the middle' (dicam horrida bella, 'I will speak of awful wars', Aen. 7.41): see J. C. McKeown, Ovid. Amores. Volume II. A Commentary on Book One (Leeds, 1989), 12.

${ }^{2}$ This analysis builds on G. B. Conte, The Rhetoric of Imitation. Genre and Poetic Memory in Virgil and Other Latin Poets, trans. C. Segal (Ithaca, NY, 1986), 85-7, who reads the epigram prefacing the three-book edition in tandem with the epigram preceding the Aeneid; for more on this, see L. Jansen, 'On the Edge of the Text: Preface and Reader in Ovid's Amores', Helios 39 (2012), $1-28$.

${ }^{3}$ Thus I am indirectly challenging readings that 'the program proper is contained in Am. 1.1-3' (B. W. Boyd, Ovid's Literary Loves. Influence and Innovation in the Amores [Ann Arbor, MI, 1997], 147), and adapting the position of N. Holzberg, Ovid. The Poet and His Work, trans. G. M. Goshgarian (Ithaca, NY, 2002), 46-7, who seems to read the first part of Amores 1 as a $2+3$.
} 
The key to the interpretation offered here is the identification of a 'false closure' at the end of Amores $1.2,{ }^{4}$ with its encouragement to Cupid to be as merciful as his kinsman Augustus:

adspice cognati felicia Caesaris armaqua uicit, uictos protegit ille manu.

Look at the happy weapons of your kinsman Caesar - with the hand that conquered, he protects those he has conquered.

The sly wit of this piece of advice is discussed by many commentators, ${ }^{5}$ but there is an extra dimension which has so far been hiding in plain sight. Ovid urges Cupid to pursue a merciful course of behaviour, an entreaty similar to the appeal of Turnus for clemency at the end of the Aeneid. The option of compassion suggested to Cupid in Amores 1.2 is one-half of the choice offered to Aeneas at the end of the Aeneid: should he kill Turnus or show mercy to him? The epic hero's inclination is to the latter until he sees the infelix ('unhappy', 12.941) baldric of Pallas. Virgil's ending effectively mythologizes the choice faced by Augustus when he was merely Octavian: should he pursue and seek revenge against the murderers of his father, or should he pardon them, as their victim, Julius Caesar, who was renowned for his clemency, might have done to his own enemies? ${ }^{3}$ The end of the Aeneid and the end of Amores 1.2 also share the issue of kinship: the pointed reference to the family tie between Caesar and Cupid, a lineage to which Aeneas of course also belongs, is a debased version of Turnus' pathetic invocation of his father, Daunus, in his unsuccessful appeal to Aeneas: fuit et tibi talis/Anchises genitor ('and such a father to you was Anchises', Aen. 12.933-4).

\footnotetext{
${ }^{4}$ On false closure, see first D. Fowler, 'First Thoughts on Closure: Problems and Prospects', MD 22 (1989), 97-101.

${ }^{5}$ J. F. Miller, 'Reading Cupid's Triumph', Cf 90 (1995), 294: 'about which readers of the Amores have argued for years'. McKeown (n. 1), 58 notes the 'playful allusion to Augustan propaganda' and 'trivial context'; cf. F. D. Harvey, 'Cognati Caesaris: Ovid Amores 1.2.51/2', WS 17 (1983), 89-90. See in particular H. Walter, 'Zum Gedichtschluss von Ovid, Am. 1,2', in W. Schubert (ed.), Ovid. Werk und Wirkung. Festgabe für Michael von Albrecht zum 65. Geburtstag (Frankfurt am Main, 1999), i.87-97, whose approach focuses much more on Propertian intertextuality.

${ }^{6}$ See, among many other discussions, R. O. A. M. Lyne, Further Voices in Vergil's Aeneid (Oxford, 1987), 187-8; D. Quint, Epic and Empire. Politics and Generic Form from Virgil to Milton (Princeton, NJ, 1993), 75-80; M. Lowrie, 'Vergil and Founding Violence', in J. Farrell and M. C. J. Putnam (eds.), A Companion to Vergil's Aeneid and Its Tradition (Malden, MA, 2010), 399 .
} 
There are verbal parallels between the final scene of the Aeneid and the couplet that closes Amores 1.2 to buttress this reading. The 'happy weapons' of Amores 1.2.51 contrast with the 'unhappy baldric' (infelix...balteus) of Aeneid 12.941-2, and the deliberate placement of uicit adjacent to uictos in Amores 1.2.51 picks up uicisti et uictum ('you have won and I am beaten', Aen. 12.936) in Turnus' plea to Aeneas. ${ }^{7}$ Notice, too, that 1.2.51 ends with the same word, arma, which began both the Amores and the Aeneid, a repetition that may mirror the wellrecognized doublings between the epic's beginning and end. For instance, the word condere appears in two different meanings ('to hide' and 'to found') very early on in the epic, and three lines from the Aeneid's end (Aen. 1.5, 1.33 12.950). ${ }^{8}$ Now condere and protegere have similar meanings (with possible suggestions of covering and hiding). ${ }^{9}$ Moreover, another possible model for the final couplet of Amores 1.2 is Propertius 2.16.41-2,10 which features condere: Caesaris haec uirtus et gloria Caesaris haec est:/illa, qua uicit, condidit arma manu ('This is the quality of Caesar and this is Caesar's glory; he sheathed his weapon with the hand by which he won'). And I wonder whether the reappearance of protegit at 1.14 .52 could be considered a stichometric repetition (that is, from the same line, 52) of the word at the same place (though not the same sedes) in the second and second-last poems of Amores 1. ${ }^{11}$ While this may strain credulity, that single other appearance of the word in the Amores does refer to the beloved covering her face while she blushes - a celebrated scene from the last book of the

${ }^{7}$ Cf. J. Wills, Repetition in Latin Poetry. Figures of Allusion (Oxford, 1996), 251.

${ }^{8}$ For the long-range link of condere, see R. J. Tarrant, Virgil. Aeneid Book XII (Cambridge, 2012), 340; cf. J. Henderson, 'The Camillus Factory: per astra ad Ardeam', Ramus 29 (2000), 6. Another example, regarding a verbal echo between Aeneas and Turnus, is treated below.

${ }^{9}$ M. Buchan, 'Ovidius Imperamator: Beginnings and Endings of Love Poems and Empire in the Amores', Arethusa 28 (1995), 64, insists on the 'hiding' implication of protegere, to match Cupid's earlier 'hidden art' (tecta... arte, 1.2.6).

${ }^{10}$ A.-F. Sabot, Ovide. Poète de l'amour dans ses oeuvres de jeunesse (Paris, 1976), 182: 'L'imitation de Properce est évidente' ('The imitation of Propertius is evident'). However, note that S. J. Heyworth, Cynthia. A Companion to the Text of Propertius (Oxford, 2007), 183, deletes the Propertian couplet as an imitation of Ovid; though cf. P. Fedeli, Properzio. Elegie libro II (Cambridge, 2005), 497-9, who keeps it! R. Dimundo, L'elegia allo specchio. Studi sul I libro degli Amores di Ovidio (Bari, 2000), 37-43, concentrates rather on Prop. 3.1-5 as a model for Ov. Am. 1.1-3; McKeown (n. 1), 33-4, 59, sees 1.2 as reflecting Prop. 3.1 or 2.16.41-2. P. A. Miller, Subjecting Verses. Latin Love Elegy and the Emergence of the Real (Princeton, NJ, 2004), 149-52, compares Am. 1.2.51-2 to the citation of Venus' lineage in Prop. 3.4.19-20, while Prop. 3.4.1 replays Aen. 1.1 in the manner of $A m$. 1.1.1.

${ }^{11}$ For stichometric repetition - which I admit is by no means a certainty - and the theory surrounding it, see D. Lowe, 'A Stichometric Allusion to Catullus 64 in the Culex', CQ 64 (2014), 862-5. 
Aeneid. ${ }^{12}$ Thus Ovid in Amores 1.14 could be referring back to a subtle game with closural elements when he had employed the same word earlier in his book.

But if the culmination of Amores 1.2 mirrors the ending of an epic, this closure comes too early for an elegiac collection of which this is famously a programmatic poem. ${ }^{13}$ It is only in the third poem that Ovid starts to talk about a girl: the order of elegiac business is reversed and we move from metrics to the poet's opus, first via the love god's arrow-shot and then by Cupid's triumph, before we get to a love object. ${ }^{14}$ Even when tossing and turning in bed at the beginning of 1.2 , the Ovidian lover is alone, ${ }^{15}$ and at the mercy not of the elegiac mistress, as might be expected, but of Amor. ${ }^{16}$ In spite of the Ovidian lover's solitude, ${ }^{17} \mathrm{I}$ would suggest that the opening scene of 1.2 is reminiscent of another episode of the Aeneid ${ }^{18}$ - the infection and incitement to war of Turnus by the fury Allecto, in the guise of the priestess of Juno, Calybe. ${ }^{19}$ The result is to inaugurate a 'second half of the Aeneid' at the start of Amores 1.2.

That said, in Book 7 Turnus is asleep when the fury in disguise first wakes him: iam mediam nigra carpebat nocte quietem ("now he was enjoying the middle of his sleep in the dark night', Aen. 7.414). It can be argued that the specification placida cum nocte iaceres ('since you were lying in the calm night', 7.427), taken as a causal rather than temporal

${ }^{12}$ See e.g. the authoritative discussion from this journal of R. O. A. M. Lyne, 'Lavinia's Blush: Vergil, Aeneid 12.64-70', GE R 30 (1983), 55-64.

${ }^{13}$ E. Reitzenstein, 'Das neue Kunstwollen in den Amores Ovids', in M. von Albrecht and E. Zinn (eds.), Ovid (Darmstadt, 1968), 218-22, a classic treatment originally dating from 1935; A. Cameron, 'The First Edition of Ovid's Amores', CQ n.s. 18 (1968), 320-33.

${ }^{14}$ The formulation of A. Sharrock, 'Ovid and the Discourses of Love: The Amatory Works', in P. Hardie (ed.), The Cambridge Companion to Ovid (Cambridge, 2002), 156.

${ }^{15}$ As stressed by G. Bretzigheimer, Ovids Amores. Poetik in der Erotik (Tübingen, 2001), 25.

${ }^{16}$ See I. M. le M. du Quesnay, 'The Amores', in J. W. Binns (ed.), Ovid (London, 1973), 10, on the reversal of audience expectation here.

${ }^{17}$ P. Hardie, Ovid's Poetics of Illusion (Cambridge, 2002), 53, links the opening sleeplessness to Cat. 50, in which Catullus at least started his writing in companionship with Calvus.

${ }^{18}$ This prominent intertextuality holds despite Sen. Con. ex. 2.2.8, with its testimony that Ovid is using here a declamation of Porcius Latro, as in the discussion of Ovid's use of controuersiae in J. T. Davis, Fictus Adulter. Poet as Actor in the Amores (Amsterdam, 1989), 4, not to mention the parallels with Meleager and Prop. 1.1.1-4: see A. de Caro, Si qua fides. Gli Amores di Ovidio e la persuasione elegiaca (Palermo, 2003), 94.

${ }^{19}$ Du Quesnay (n. 16), 45, n. 40, identifies Dido at Aeneid 4.1 as a parallel for 'sleeplessness as a sign of love'. She can be closely affiliated with Turnus as an 'enemy' of Aeneas. For genealogical analysis, appropriate in the context of the kinship of Augustus and Cupid, see B. Hannah, 'Manufacturing Descent: Virgil's Genealogical Engineering', Arethusa 37 (2004), 141-64. For the eroticization of Turnus, see J. D. Reed, Virgil's Gaze. Nation and Poetry in the Aeneid (Princeton, NJ, 2007), 44-72, esp. 61-3 on his similarity to Dido. 
cum-clause, likewise reflects the peacefulness of Turnus' sleep; ${ }^{20}$ I agree that carpere implies step-by-step movement into ever-deeper sleep. ${ }^{21}$ Rather, it is Amata who was already convulsed with worry before the advent of Allecto: femineae ardentem curaeque iraeque coquebant ("female cares and angers were cooking her, blazing', 7.345). Indeed, in that case the snake which Allecto inflicts on the queen is unfelt: uoluitur attactu nullo, fallit furentem ('it rolls with no touch, it deceives the raging woman', 7.350). Given the similarity with Ovid's understanding of his own situation (although the two options are presented in reverse order), it seems reasonable to ask whether Ovid's persona is similarly experiencing femineae curae: a woman's cares, or cares regarding a woman?

However, when rebuffed, Allecto causes Turnus to tremble and then his eyes to become fixed (7.446-7); she 'turns her fiery gaze' (flammea torquens/lumina, 7.448-9) on him, and she also throws a missile at him:

sic effata facem iuueni coniecit et atro

lumine fumantis fixit sub pectore taedas

$(7.456-7)$

When she had spoken like that she threw a torch at the young man and fixed smoking brands in his heart with black light.

The result, in the next line, is that 'a huge fear breaks his sleep', and Turnus sweats down his bones (7.458-9), just as the speaker of Amores 1.2 is uacuus somno and feels pain through his bones ( $\mathrm{Am}$. 1.2.3-4). Yet if Turnus was already awake, and he did manage to speak mockingly to Allecto (Aen. 7.435-44), then a problem arises for an understanding of the passage as realistic: did he see all this happen? ${ }^{22}$ The question is pertinent to Amores 1.2 because the speaker wonders how the missiles of Cupid had entered his heart without him knowing (1.2.6, followed by sic erit, 'that must be it', 1.2.7). In any case the Ovidian speaker talks shortly after about 'having seen' (uidi, 11-12) torches blazing and dying for himself. ${ }^{23}$ Likewise, although Allecto (in the persona of Calybe) barely mentions the issue of marriage to Lavinia (coniugium, Aen. 7.433), Turnus, when infected by Allecto, experiences

${ }^{20}$ So J. O'Hara, Death and the Optimistic Prophecy in Vergil's Aeneid (Princeton, NJ, 1990), 68-9.

${ }^{21}$ See N. Horsfall, Aeneid 7. A Commentary (Leiden, 2000), 284.

${ }^{22}$ Noted by D. Feeney, The Gods in Epic (Oxford, 1991), 170.

${ }^{23}$ This declaration of authenticity balances the observations of J. Moles, 'The Dramatic Coherence of Ovid, Amores 1.1 and 1.2', CQ n.s. 41 (1991), 553, on dicitur ('it is said', 1.1.4) as 'distancing formula' to represent the dramatic development from $\mathrm{Am} .1 .1$ to 1.2 (in 1.2.10, fertur ironically means 'it is carried' rather than 'it is said'). 
a love (amor, 7.461) - but, paradoxically enough, for iron (ferri), meaning war. To be sure, he is going to war for a woman, but again the situation arguably matches Ovid's persona's lack of a mistress. If in the Aeneid 7 passage Virgil 'grafts elegiac language into epic diction', ${ }^{24}$ I submit that Ovid's speaker owes something in turn to Virgil's anti-hero Turnus, together with his vocal champion Amata. ${ }^{25}$

At the beginning of Amores 1.2, 'the subject matter is mundane, domestic almost, and the language is correspondingly simple'. ${ }^{26}$ However, the tone is soon heightened with the set-piece description of Cupid's triumph, ${ }^{27}$ with a specific nod to the elegiac predecessor Tibullus (as 1.2.34 modifies Tib. 2.5.118). Importantly, we have moved from Aeneid 7 to Aeneid 8: in Amores 1.2 the focus on the triumphal chariot as the gift of a uitricus ('stepfather', 1.2.24), which has led to debate over whether Mars or Vulcan is meant, reproduces the appearance of Mars's chariot when Venus goes to ask for Aeneas' arms from Vulcan in Aeneid 8:28

parte alia Marti currumque rotasque uolucris instabant, quibus ille uiros, quibus excitat urbes

(Aen. 8.433-4)

In another part they were pressing on with a chariot with winged wheels for Mars, with which he rouses men, with which he rouses cities.

Likewise, we must bear in mind the observation that Virgil's ecphrastic description of the shield of Aeneas takes a structure which reflects the progression of the triumph which winds up as its centrepiece. ${ }^{29}$ It is noteworthy that Ovid alludes, in his description of Mens Bona ('Good Sense') and Pudor ('Modesty') in chains, to a painting by

${ }^{24}$ I. Ziogas, 'The Permanence of Cupid's Metamorphosis in the Aeneid', Trends in Classics 2 (2011), 160 .

${ }^{25}$ See S. Casali, 'Altre voci nell' Eneide di Ovidio', $M D 35$ (1995), 70-1, on how the Aeneid's hostile voices become Ovid's epic voice in the 'Little Aeneid' of the Metamorphoses, with a focus on Turnus' 'promised bride' (Met. 14.451).

${ }^{26}$ D. West, 'Amores 1.1-5', in C. S. Kraus, J. Marincola, and C. Pelling (eds.), Ancient Historiography and Its Contexts. Studies in Honour of A. F. Woodman (Oxford, 2010), 144.

${ }^{27}$ But see B. Weinlich, Ovids Amores. Gedichtfolge und Handlungsablauf (Stuttgart, 1999), 28: 'die Argumentation entbehrt nicht einer gewissen Komik' ('the argument does not lack a certain humour').

${ }^{28}$ See L. Athanassaki, 'The Triumph of Love and Elegy in Ovid's Amores 1,2', MD 28 (1992), 129.

${ }^{29}$ A. G. McKay, 'Non enarrabile textum? The Shield of Aeneas and the Triple Triumph in 29 в.c. (Aen. 8.630-728)', in H.-P. Stahl (ed.), Vergil's Aeneid. Augustan Epic and Political Context (London, 1998), 199-221. 
Apelles set up in the Forum of Augustus that featured a bound Furor ('Frenzy'), ${ }^{30}$ making the scene a parodic ecphrasis, and therefore a debased form of the description of Aeneas' shield. Indeed, we might consider that the Triple Triumph on the Shield enacts in ecphrasis the closure prophesied by Jupiter in Aeneid 1.286-96 with the coming of Caesar. Thus it is possible to see a negative reminiscence of that pro-Augustan passage from the Aeneid, Jupiter's prophecy to Venus of future glory for Rome (Aen. 1.291-6), in Ovid's reference to the chained personifications. ${ }^{31}$ Cupid's triumph in Amores 1.2 unbinds the Furor who had been bound up in Jupiter's telling (Aen. 1.294-6), undoing the triumphal, pacifying conclusion of the Shield passage. Moreover, that endpoint, chronologically the latest historical event described in the epic, can be assimilated with the narrative closure of Aeneid 12, where 'Frenzy' is also unbound when Aeneas is 'blazing with fury and rage' (furiis accensus et ira, 12.946). ${ }^{32}$ As we progress through Amores 1.2, we are also progressing through the second half of the Aeneid, until we reach its violent end with its hard choice in the poem's final couplet.

But it is certainly the case that a girl is still missing from Ovidian elegy until Amores 1.3 at least - so one valid way of reading the second half of the Aeneid, as a conflict of suitors over the blushing would-be bride Lavinia (let alone the first half with Dido), is lacking from the Ovidian response to the epic that I have mooted in Amores 1.2.33 Nevertheless, further Virgilian aspects are at play in Amores 1.2. ${ }^{34}$ It is tempting to claim that the closing couplet, which I have linked with the end of the epic, has affinities with the advice of Anchises in Aeneid 6: parcere subiectis et debellare superbos ('to spare the conquered and war down the proud', 6.853); ${ }^{35}$ the imperative parce in Amores

${ }^{30}$ McKeown (n. 1), 48.

31 Miller (n. 10), 164-6, after McKeown (n. 1), 48-9.

${ }^{32}$ I owe this point to the anonymous reviewer.

${ }_{33}$ This possibility comes into play later in the three-book collection: witness the development of $A m$. 1.2's triumph motif in $A m$. 2.12(13), with Lavinia a justification for war at 2.12(13).21-2. See J. Booth, Ovid. The Second Book of Amores (Warminster, 1991), 64-5.

${ }^{34}$ G. K. Galinsky, 'The Triumph Theme in the Augustan Elegy', WS 82 (1969), 91-3, lists several parallels from the Georgics; R. Armstrong, Ovid and His Love Poetry (London, 2005), 29, observes the similarity of cedimus. . .cedamus ('I yield. . let me yield!', Am. 1.2.9-10) and the famous line of Gallus in Verg. Ecl. 10.69 (nos cedamus Amori, 'let me yield to Love'), as did D. F. Kennedy, The Arts of Love. Five Studies in the Discourse of Roman Love Elegy (Cambridge, 1993), 81, asserting that 'erotic experience becomes a web of intertextual allusion'.

${ }^{35}$ Galinsky (n. 34), 93; J. Barsby, Ovid's Amores Book One (Oxford, 1979), 49; M. Labate, L'arte di farsi amare. Modelli culturali e progetto didascalico nell'elegia ovidiana (Pisa, 1984), 68-9, who also pushes the additional intertext of Euripides' Hippolytus. 
1.2.50 is no accident. ${ }^{36}$ That advice could also be said to follow a triumph-like set piece, in the form of the Parade of Heroes from Roman History shown to Aeneas (Aen. 6.760-846). ${ }^{37}$ As the parade is midway through the epic, we do not have to decide that the end of Amores 1.2 is a total closure, only that it is possible to read it as one.

However, there is a further Virgil-inspired detail in the closing couplet of Amores 1.2 which makes us think hard about the political ramifications of the elegist's literary decisions. The phrase felicia arma ('happy weapons') is used earlier than our poem only in the Aeneid, to describe the arms of Ufens (felicibus armis, 'with his happy weapons', 7.745). ${ }^{38}$ This forms part of his vignette in yet another triumph-like locus, the Catalogue of Heroes - except that Ufens fights on the wrong side, that of the Latins. If we notice this identification, we start to wonder about what it means for Augustus to be associated with a historic enemy. ${ }^{39}$ The true meaning of clemency, it would seem, is that conqueror and conquered can switch roles: each side can exchange its 'happy weapons'. ${ }^{40}$

But there is more for the suspicious and discerning reader of Ovid, because the enemies of Aeneas (and by extension of Cupid's family) in the epic can be linked not to Augustus but to the love elegist himself, downtrodden in the love god's triumph. When we meet Ufens again in the Aeneid, it will be in a charged situation that has implications for Ovid himself: the immediate aftermath of the death of Pallas (10.517-20):

\footnotetext{
Sulmone creatos quattuor hic iuuenes, totidem quos educat Vfens, uiuentis rapit, inferias quos immolet umbris captiuoque rogi perfundat sanguine flammas.
}

He grabs four youths alive, sons of Sulmo, then four raised by Ufens, to sacrifice as victims to the shades below [of Pallas], to pour out as captive blood on the flames of the pyre.

\footnotetext{
${ }^{36}$ Even if this parce has a different sense from that of parcere subiectis, the anonymous reviewer reminds me that McKeown (n. 1), 58, does entertain the possibility of Ovid being influenced in his choice of expression by the literal sense, 'spare'.

${ }^{37}$ Note that this vision has more precise affinities with a Roman aristocratic funeral: T. M. O'Sullivan, Walking in Roman Culture (Cambridge, 2011), 53, with references.

${ }^{38}$ McKeown (n. 1), 59.

${ }^{39}$ Walter (n. 5), 94-5, makes the couplet about Mark Antony, as Propertius would have had it.

${ }^{40}$ Though note that in Jupiter's Aen. 1 prophecy, bound Furor sat on saeua...arma, 'savage weapons' (Aen. 1.295).
} 
This infamous scene shows an unmerciful Aeneas preparing to sacrifice children of Ufens and of Sulmo. ${ }^{41}$ While Sulmo here seems to have been another Latin warrior (the name only appears elsewhere in the Aeneid as the first victim of Nisus when Euryalus has been killed, 9.412), Sulmone can be interpreted as an ablative of location: thus some of the sacrificial victims could be said to have been 'born at Sulmo'. ${ }^{42}$ Of course, another famous person 'born at Sulmo' was Ovid (in the Amores at 2.16.1, 3.15.11). In my view, Ovid has actively encouraged a creative misreading of Virgil's Aeneid in Amores 1.2, which makes me less inclined to trust that Cupid, kinsman not only of Augustus but also of Aeneas, will be merciful to the elegiac poetlover. ${ }^{43}$ In that case, we might want to ask what not being merciful entails: does it imply, on analogy with the end of the Aeneid, that Cupid will kill and therefore silence the poet, who is already wounded (Am. 1.2.29)? That would put a premature stop to the Amores. ${ }^{44}$

Yet we must remember that Ovid's condensation of the Aeneid near the beginning of the Amores in the service of a narratological game has Virgilian precedent itself in the epic's early stages. In the shipwreck scene in Book 1 the fate of the poem hangs in the balance: if Aeneas perishes with his ships, then his founding of Rome cannot so much as get started. In this fraught atmosphere, the opening two words of the epic resurface amid the floating debris: arma uirum tabulaeque et Troia gaza per undas ('arms of men, planks, and the treasure from Troy through the waves', Aen. 1.119). ${ }^{45}$ So, too, the very ending of the poem is foreshadowed in that same scene. Aeneas' very first

${ }^{41}$ See e.g. S. J. Harrison, Vergil. Aeneid Book 10 (Oxford, 1991), 202-3.

${ }^{42}$ Likewise, 'Ufens is a Volscian river turned into the leader of Aequians from Nersa': S. Mack, 'The Birth of War: A Reading of Aeneid 7', in C. Perkell (ed.), Reading Vergil's Aeneid. An Interpretive Guide (Norman, OK, 1999), 130.

${ }^{43}$ Contra Boyd (n. 3), 151. For the difficulty, noted by the anonymous reviewer, that the 'happy weapons' are not Ovid's, who should correspond with Ufens, I would suggest that - in the same way that Aeneas is assimilated to his opponents' savagery - Augustus' felicia arma in 1.2.49 could have been stripped from the enemies he has conquered (i.e. from Ovid).

${ }^{44}$ At the same time, we could consider the pervasive erotic (orgasmic?) implications of death for Roman love elegy: the anonymous reviewer suggests to me that, for instance, the likely Gallan echo mentioned above (n. 34), earlier in the poem (1.2.9-10 Verg. Ecl. 10.69) could point back to Virgil's description of Gallus, indigno cum Gallus amore peribat ('when Gallus was perishing with unworthy love', Ecl. 10.10).

${ }^{45}$ A nuance noticed by e.g. N. P. Gross, 'Mantles Woven with Gold: Pallas' Shroud and the End of the Aeneid', CF 99 (2003-4), 138, and already with a narratological slant in C. Segal, 'Art and the Hero: Participation, Detachment, and Narrative Point of View in Aeneid 1', Arethusa 14 (1981), 71. For more on Ovid's theft of the Virgilian catchphrase arma uirum ('arms and the man'), see A. Barchiesi, The Poet and the Prince. Ovid and Augustan Discourse (Berkeley, CA, 1997), pp. 16-17. 
appearance shows him un-heroically fearful: soluuntur frigore membra ('his limbs are slack with chill', 1.92), which is the same phrase applied to Turnus in the epic's penultimate line (12.951), when the tables are turned and Aeneas has dealt him the death blow. And in this context the mention of Caesar by name at Amores 1.2.51 in relation to clemency replays the old dispute over which Caesar (Aen. 1.286), Julius or Augustus, is meant in Jupiter's Aeneid 1 prophecy. ${ }^{46}$

As for another celebrated feature of the Aeneid's narrative complexity, the 'proem in the middle', ${ }^{47}$ that too has an unexpected aspect relevant to Ovid's purposes in the Amores: its dedication is to Erato, the Muse of love poetry. ${ }^{48}$ But this could be a further similarity not only with Amores $1.1^{49}$ but with Amores 1.2 as well. The latter's opening styles itself as a new surprise beginning after the focus on the nuts and bolts of metrics in Amores 1.1: a 'proem in the middle' of the opening, so to speak, ${ }^{50}$ even if - to be more precise - the address to Erato might take place at the end of Amores 1.1 (Musa, 1.1.30). A broad result of these points is that Ovid ends up writing epic after all, joining up two poems, which purported to be discrete 'snapshots' rather than coherent narrative, ${ }^{51}$ but also flagrantly disobeying Cupid's Amores 1.1 order not to write epic - with the creation of a surreptitious 'mini-Aeneid'. Such disobedience goes against the stated theme of Amores 1.2: the necessity of surrender to Cupid. Ovid's subversiveness makes the trail that I have identified, which leads to Aeneas' 'human sacrifice', all the more uncomfortable and worrying, the more so because it comes so close to the outset of the poet's literary and erotic collection of Amores.

IAN GOH Q1

ian.goh@manchester.ac.uk

${ }^{46}$ Servius thought Julius, while Turnebus thought Augustus: see e.g. O'Hara (n. 20), $155-63$.

${ }^{47}$ See G. B. Conte, 'Proems in the Middle', in F M. Dunn and T. Cole (eds.), Beginnings in Classical Literature (Cambridge, 1992), 147-59, a first English version of a now celebrated treatment.

${ }^{48}$ See the reminder of the first scholar to treat this issue in G. B. Conte, The Poetry of Pathos. Studies in Virgilian Epic, trans. E. Fantham (Oxford, 2007), 185-6; see also Mack (n. 42), $128-34$.

${ }^{49}$ See n. 1 above.

${ }^{50}$ See e.g. A. R. Sharrock, 'Ovid', in B. K. Gold (ed.), A Companion to Roman Love Elegy (Malden, MA, 2012), 78. Barchiesi (n. 45), 16 ,notes the 'marked inversion' of Ovid's career, starting, apparently, with epic rather than working its way towards that goal.

${ }^{51}$ See P. Salzman-Mitchell, 'Snapshots of a Love Affair: Amores 1.5 and the Program of Elegiac Narrative', in G. Liveley and P. Salzman-Mitchell (eds.), Latin Elegy and Narratology. Fragments of Story (Columbus, OH, 2008), 45-7, primarily on Am. 1.1. 